Bull. Fac .Agric., Cairo Univ., 68:237-250 (2017).

\title{
EFFECT OF CUTTING INTERVAL AND INTERCROPPING SYSTEM OF MONOCOT EGYPTIAN CLOVER WITH BARLEY ON GRAIN, FORAGE YIELD AND NUTRITIVE VALUE OF MIXTURE.
}

(Received: 28.11.2017)

\author{
By \\ A.M. Abdel-Galil , * H.A. Ashmawy, ** S.S.M. Abo Feteih and * H.E.A. El-Nady \\ Crop intensification Research Department, *Barley Research Department, ** Forage Crop Research \\ Department, Field Crops Research Institute, Agriculture Research Center, Giza
}

\begin{abstract}
The present experiment was carried out at Giza Experiment Station, ARC, Giza, Egypt, during 2013/14 and 2014/15 winter seasons. The aim was to study the effect of three cutting intervals after sowing date [50 days $\left(\mathrm{C}_{1}\right), 75$ days $\left(\mathrm{C}_{2}\right)$ and at harvest 150 days $\left(\mathrm{C}_{3}\right)$ ] under three intercropping systems barely and berseem $\mathrm{T}_{1}=(100 \%: 25 \%), \mathrm{T}_{2}=(100 \%: 50 \%)$ and $\mathrm{T}_{3}=(100 \%: 75 \%)$ of barley (c.v. Giza 2000): Fahl berseem, respectively. In addition to two sole stands of the two crops according to the technical measures for both crops, to examine its effect on grain yield for barely and forage yield from a mixture of barley and Fahl berseem, competitive relationships and total income. The experiment was arranged in split plot based on randomized complete block design in three replications. Results showed that cutting at harvest day $150 \mathrm{~d}\left(\mathrm{C}_{3}\right)$ had significant effect on spike length, grain number spike ${ }^{-1}, 1000$ grain weight and straw yield of barley. Whereas, cutting after 75 day $\left(C_{2}\right)$ had significant effect on fresh yield, dry forage, nutrient value of barley and Fahl berseem mixture. Effect of intercropping system $\left(\mathrm{T}_{3}\right)$ was meaningful on plant height, spike length, grain number spike ${ }^{-1}$, grain yield and straw yield of barley, as well as intercropping system $\left(\mathrm{T}_{3}\right)$ had significant effect on the number of branches plant ${ }^{-1}$, leaves stem $^{-1}$ ratio and fresh, dry yields, nutritive value of barley and Fahl berseem mixture. Cutting interval $x$ intercropping system $\left(\mathrm{C}_{3} \mathrm{xT}_{3}\right)$ had significant effect on spike length, grain number spike ${ }^{-1}, 1000$ grain weight, biological yield, grain yield and straw yield of barley in both seasons. Whereas, cutting interval after 75 days and intercropping system $\left(\mathrm{C}_{2} \mathrm{xT}_{3}\right)$ gave the highest values of fresh, dry forage yield and nutritive value of barley and fahl berseem mixture in both seasons. The highest land equivalent Ratio (LER) and economic returns . $\left(\mathrm{C}_{2} \mathrm{xT}_{3}\right)$ demonstrated superiority of the intercropping system to sole barley culture. It is evident that cutting interval at 75 day and cropping system $\mathrm{T}_{3}(100 \%$ barley $+75 \%$ fahl berseem) may be the best practice to maximize the economic return of grain and forage yields for farmer.
\end{abstract}

Key words: Barley (Hordeum vulgar L), Fahl Berseem (Trifolium alexandrinum L), Cutting intervals, Intercropping systems, Nutritive value, LER, Total income.

\section{INTRODUCTION}

Increasing agricultural production to meet increasing demand for food sources is inevitable (FAO, 2006). Intercropping is the cultivation of two or more plant species at the same time in the same field in their growth period where most of the plants are in close proximity to each other (Caballero et al., 2001). One of the main reasons that farmers all around the world are eager to use intercropping system is that the yield obtained from intercropping is more than monoculture in the same field (Yang et al., 2009). Increasing production at intercropping may be related to reduction of weed growth, reduction of pest and disease damages (Sekamatte et al., 2003), and more growth rate and better use of available resources (Gustave et al. 2008). Cutting interval is an important agronomic factor which greatly influences the micro climate of the field and eventually yields and quality parameters of agricultural crops. Potential benefits of intercropping berseem clover with cereal crops include increased total dry matter (DM) yields, improved forage quality, reduced fertilizer needs, and increased subsequent crop yield (Stout et al. 1997). Abou- Kerisha, et al. (1996) indicated that seeding $75 \%, 50 \%$ and $25 \%$ fahl berseem, plus $25 \%, 50 \%$ and $75 \%$ barley in 
complement mixtures gave more yield than pure fahl berseem. They also evidenced that mixing fahl berseem with barley resulted in higher values barley traits as compared to pure stand barley. Berseem improved the forage quality and yields of barley-ryegrass-legume intercrops more than did annual Medicago and Lespedeza species. Radwan et al., (1983) reported that seed of fahl berseem can be produced by interseeding with grain barley without reducing grain yield. Intercropping of fahl berseem with barely aimed to providing the farmers green forage and rising grain yield of barely with improved soil fertility. The main aims of this study were to examine the effects of cutting intervals and intercropping systems on forage yield, forage nutritive value, grain yield and beneficial index of intercropping system, improving the proportion of protein, fiber and forage yield competitive relationships and total income, in a mixture of barley and fahl berseem.

\section{MATERIALS AND METHODS}

Two field experiments were carried out at Giza Experiment Station, ARC, Giza, Egypt, during 2013/2014 and 2014/2015 seasons. Soil was analyzed according to Page et al. (1982). Soil texture was clay loamy and its characteristics are shown in Table (1).

The objective of this study was to investigate the effect of cutting intervals under three intercropping system of barley (Hordum vulgare L.); Giza 2000 with the Mono-cut Egyptian clover (fahl berseem). Three cutting intervals and three intercropping systems was arranged in split plot based on randomized complete block design in three replications. The main plots were devoted for cutting intervals, whereas intercropping systems occupied subplots.

The tested treatments were as follows:

Cutting intervals $(\mathbf{C})$ after sowing date $\left(15^{\text {th }}\right.$ November in two years) :

C1- was taken after 50 days, C2- interval after 70 days and C3- after 150days at harvested day.
Intercropping systems (T) (based on seed weight).

T1-100\% barley $\left(50 \mathrm{~kg} \mathrm{fed}^{-1}\right)+25 \%$ fahl berseem $\left(5 \mathrm{~kg} \mathrm{fed}^{-1}\right)$.

T2-100\% barley $\left(50 \mathrm{~kg} \mathrm{fed}^{-1}\right)+50 \%$ fahl berseem $\left(10 \mathrm{~kg} \mathrm{fed}^{-1}\right)$.

T3-100\% barley $\left(50 \mathrm{~kg} \mathrm{fed}^{-1}\right)+75 \%$ fahl berseem $\left(15 \mathrm{~kg} \mathrm{fed}^{-1}\right)$.

In addition, two sole stands of the two crops as recommended on seed rates barley 50 $\mathrm{kg} \mathrm{fed}^{-1}$ and fahl berseem $20 \mathrm{~kg} \mathrm{fed}^{-1}$, were used.

Barley was sown in plot size $10.0 \mathrm{~m}^{2}(10$ rows $0.5 \mathrm{~m}$ length at a distance at $20 \mathrm{~cm}$ apart) and fahl berseem was broadcasted in barley plots. Phosphorus and potassium fertilizers were applied prior to land preparation at the rate of 30 $\mathrm{kg} \mathrm{P}_{2} \mathrm{O}_{5}$ fed $^{-1}$ and $24 \mathrm{~kg} \mathrm{~K}_{2} \mathrm{O}$ in the form of super phosphate $\left(15.5 \% \quad \mathrm{P}_{2} \mathrm{O}_{5}\right)$ and potassium sulfate $\left(48 \% \mathrm{k}_{2} \mathrm{O}\right)$, respectively. Nitrogen fertilizer was applied in the form of ammonium nitrate $(33.5 \%)$ in three equal doses; the first dose was at sowing and the other two doses were applied at 21 and 35 days after sowing.

At cutting: ten plants from the inner row of barely and berseem intercropping and solid crops were taken randomly to determine yield parameters, while the yield $\mathrm{fed}^{-1}$ was determined from the whole plots.

The studied growth and yield parameters are recorded as follows (after separating the barley and fahl berseem in plots):

A. barley: plant height $(\mathrm{cm})$, spike length $(\mathrm{cm})$, number of kernels spilke ${ }^{-1}$, spike kernels weight (g),1000-kernel weight (g), biological yield (ton $\mathrm{fed}^{-1}$ ), grain yield $\left(\right.$ ton $\mathrm{fed}^{-1}$ ), straw yield (ton $\mathrm{fed}^{-1}$ ), fresh forage yield and dry forage yield.

B. Berseem: (Mono-cut variety) plant height $\mathrm{cm}$, no. of branches, leaves/ stem ratio\%, fresh yield ton fed ${ }^{-1}$, dry yield ton fed ${ }^{-1}$, seed yield ton fed $^{-1}$ and straw yield ton fed ${ }^{-1}$

\section{Agronomic and Chemical Composition}

Nutritive value; sub sample of $0.5 \mathrm{~m} \times 0.5$ $\mathrm{m}=0.25 \mathrm{~m}^{2}$ weighted as fresh and dried at $65^{\circ} \mathrm{C}$ and weighed to determine DM \% for all treatments. Plant samples of each unit were

Table (1): Mechanical and chemical analysis of the experimental soil.

\begin{tabular}{|c|c|c|c|c|c|c|c|c|}
\hline $\begin{array}{c}\text { Coarse } \\
\text { Sand(\%) }\end{array}$ & $\begin{array}{c}\text { Fine } \\
\text { Sand\% }\end{array}$ & Silt $(\%)$ & \multicolumn{2}{|c|}{$\operatorname{Clay}(\%)$} & Soil texture & \multicolumn{2}{|c|}{$\mathbf{O M}$} & $\mathrm{CaCO} 3(\%)$ \\
\hline 6.0 & 5.3 & 38.3 & 50. & & Clay Loamy & \multicolumn{2}{|c|}{$\mathbf{1 . 1 7}$} & 1.43 \\
\hline \multirow[t]{2}{*}{ pH } & EC & \multicolumn{4}{|c|}{ Cations (meq/l) } & \multicolumn{3}{|c|}{ Anions (meq/l) } \\
\hline & $(\mathrm{dS} / \mathrm{m})$ & $\mathrm{Ca}^{++}$ & $\mathrm{Mg}^{++}$ & $\mathrm{Na}^{+}$ & $\mathbf{K}^{+}$ & $\mathrm{HCO}^{-}$ & $\mathrm{Cl}^{-}$ & $\mathrm{SO}^{-}$ \\
\hline 7.80 & 1.15 & 9.32 & 2.88 & 22.20 & 0.76 & 1.40 & 10.60 & 16.05 \\
\hline
\end{tabular}


collected, weighted, dried and ground in a grinding mill. The samples were analyzed according to AOAC (2000) to determine crude protein $(\mathrm{CP})$, crude fiber $(\mathrm{CF})$. Total digestible nutrient (TDN) was calculated as TDN= 50.41+1.04CP-0.07CF, according to Church (1979) and digestible crude protein (DCP was calculated as $\mathrm{DCP}=(\mathrm{CP} X \mathrm{X} 0.9115)$ - 362) according to Mcdonald et al. (1978).

\section{Land equivalent ratio (LER)}

LER is determined as the sum of the fractions of the yield of the intercrops relative to their sole crop yields (Willey and Rao, 1980). Land Equivalent Ratio (LER) was determined according to the following formula:

$$
L E R=\frac{Y_{a b}}{Y_{a a}}+\frac{Y_{b a}}{Y_{b b}}
$$

Where Yaa $=$ Pure stand yield of barley, $\mathrm{Ybb}=$ Pure stand yield of fahl berseem, $Y a b=$ Mixture yield of a when combined with $b$. Yba $=$ Mixture yield of $b$ when combined with $a$.

\section{Economic evaluation}

The economic evaluation included the following three parameters:

1- Average of input variables as well as the total costs of inter cropping berseem Fahl and barely production including fertilization treatments and other cultural practices applied during the growth stages (i.e., average land rent is not included).

2- Net farm return of inter cropping berseem Fahl and barely production as affected by the applied treatments. It is calculated as the difference between the grain and forage yield value (according to the actual price) and the total costs.

All fertilizers and seed prices as well as the costs of all farm operations are based on the official and the actual market prices determined by the Egyptian Ministry of Agriculture (Anonymous, 2014). Total costs included values of production tools and requirements such as seeds, fertilizers, irrigation, laborers, power, machinery and other general or different costs.

The obtained data were statistically analyzed according to Snedecor and Cochran (1980). Bartelett's test of homogeneity indicated no statistical evidence for heterogeneity. Thus, combined analyses of variance for two experimental sites in each experiment were done. Treatment means were compared using least significant differences LSD at probability level of $5 \%$.

\section{RESULTS AND DISCUSSION}

\subsection{Agronomic traits of barley crop}

\subsubsection{Plant height and Spike length}

Data presented in Table (2) show the means of plant height and spike length growth characters in 2013/2014 and 2014/2015. Plant characters such as plant height and spike length, were significantly affected due to the cutting intervals. Without cutting at harvest day $\left(\mathrm{C}_{3}\right)$ gave the highest plant height (87.35 and 93.98 $\mathrm{cm})$ and spike length $(8.50$ and $9.90 \mathrm{~cm})$ in $2013 / 14$ and 2014/2015, respectively. It also showed significant effect on plant height and spike length due to the intercropping system, where (barley $100 \%$ + barseem $75 \%$ ) $\left(\mathrm{T}_{3}\right)$ gave the highest plant height $(70.33$ and $75.67 \mathrm{~cm})$ and highest spike length $(8.77$ and $9.10 \mathrm{~cm})$ in the $1^{\text {st }}$ and $2^{\text {nd }}$ seasons, respectively.

The most success in high plant density at intercropping is related to more attraction of sunlight at early plant sowing stage and better competition of this system with weed (Boquet $e t$ al., 2003).

For the interaction effect of cutting intervals $\mathrm{x}$ intercropping system, on plant height, the higher values $(88.3$ and $95.3 \mathrm{~cm})$ were obtained from use $\left(\mathrm{C}_{3} \times \mathrm{T}_{3}\right)$ in the $1^{\text {st }}$ and $2^{\text {nd }}$ season respectively. While, the tallest spike length, (10.2 and 9.7) were obtained from use $\left(C_{1} \times T_{1}\right)$ in the $1^{\text {st }}$ and $2^{\text {nd }}$ season respectively.

The combined analysis over the two seasons showed significant effects for the interaction of cutting intervals $\mathrm{x}$ intercropping system, the tallest plants $(91.8 \mathrm{~cm})$ were produced by $\left(\mathrm{C}_{3} \mathrm{x}\right.$ $\mathrm{T}_{3}$ ), while the tallest spike length $(10.15 \mathrm{~cm})$ was produced by $\left(\mathrm{C}_{1} \times \mathrm{T}_{2}\right)$. Increase of barley plant height at intercropping may be related to increasing of $\mathrm{N}$ availability which was fixed by legume. These results agree with Sara et al., (2014) who investigate the intercropping of barley (Hordeum vulgare L.) and (Trifolium resupinatum L.)

\subsubsection{Yield and yield component of barley}

\subsubsection{Number kernels spike ${ }^{-1}$, Spike kernels} weight and 1000-kernel weight

Results in Table (3) showed that the number of kernels Spike $^{-1}$, spike kernels weight and 1000-kernel weight were significantly affected by cutting intervals $(\mathrm{p} \leq 0.05)$. The results showed that the highest number of grains spike ${ }^{-1}$ (58.85 and 53.1), spike kernels weight (3.59 and $5.65 \mathrm{~g})$ and the highest 1000-kernel weight (61.3 and $59.1 \mathrm{~g}$ ) were recorded by cutting intervals $\left(\mathrm{C}_{3}\right)$, in the $1^{\text {st }}$ and $2^{\text {nd }}$ season respectively. 
Table (2): Average of plant height and spike length of barley as affected by cutting interval and intercropping system and their interaction in 2013/14 and 2014/15 at Giza.

\begin{tabular}{|c|c|c|c|c|c|c|}
\hline \multirow[b]{3}{*}{ Treatments } & \multirow{2}{*}{\multicolumn{2}{|c|}{$\begin{array}{c}2013 / 2014 \\
\text { Barley }\end{array}$}} & \multirow{2}{*}{\multicolumn{2}{|c|}{$\begin{array}{c}\text { 2014/2015 } \\
\text { Barley }\end{array}$}} & \multirow{2}{*}{\multicolumn{2}{|c|}{$\begin{array}{c}\text { Combine } \\
\text { Barley }\end{array}$}} \\
\hline & & & & & & \\
\hline & $\begin{array}{c}\text { Pl-Ht } \\
(\mathrm{cm})\end{array}$ & $\begin{array}{l}\text { SP-L } \\
(\mathrm{cm})\end{array}$ & $\begin{array}{c}\text { Pl-Ht } \\
(\mathrm{cm})\end{array}$ & $\begin{array}{l}\text { SP-L } \\
(\mathrm{cm})\end{array}$ & $\begin{array}{l}\text { Pl-Ht } \\
\text { (cm) }\end{array}$ & $\begin{array}{r}\text { SP-L } \\
(\mathrm{cm})\end{array}$ \\
\hline Cutting": & & & & & & \\
\hline $\mathbf{C}_{1}$ & 61.33 & 9.60 & 65.85 & 8.55 & 63.59 & 9.08 \\
\hline $\mathbf{C}_{2}$ & 48.20 & 8.00 & 51.68 & 8.15 & 49.94 & 8.08 \\
\hline $\mathrm{C}_{3}$ & 87.35 & 8.50 & 93.98 & 9.90 & 90.66 & 9.20 \\
\hline LSD at 5\% & 3.4 & 0.6 & 3.2 & 0.7 & 2.9 & 0.4 \\
\hline $\begin{array}{l}\text { Intercropping } \\
\text { system }^{* *}:\end{array}$ & & & & & & \\
\hline $\mathbf{T}_{1}$ & 66.43 & 8.63 & 69.57 & 8.10 & 68.00 & 8.37 \\
\hline $\mathbf{T}_{2}$ & 65.90 & 8.83 & 68.87 & 8.63 & 67.38 & 8.73 \\
\hline $\mathbf{T}_{3}$ & 70.33 & 8.87 & 75.67 & 9.10 & 73.00 & 8.73 \\
\hline $\mathbf{T}_{4}$ & 59.83 & 8.77 & 67.90 & 9.63 & 63.87 & 8.99 \\
\hline LSD at $5 \%$ & 4.0 & 0.5 & 3.2 & 0.5 & 2.3 & 0.3 \\
\hline $\mathrm{C}_{1} \times \mathrm{T}_{1}$ & 63.3 & 10.2 & 60.7 & 9.7 & 62.0 & 9.95 \\
\hline $\mathrm{C}_{2} \times \mathrm{T}_{1}$ & 48.3 & 7.2 & 52.0 & 8.3 & 50.2 & 7.75 \\
\hline $\mathrm{C}_{3} \times \mathrm{T}_{1}$ & 87.7 & 8.5 & 96.0 & 9.3 & 91.8 & 8.90 \\
\hline $\mathrm{C}_{1} \times \mathrm{T}_{2}$ & 66.0 & 10.0 & 69.0 & 10.3 & 67.5 & 10.15 \\
\hline $\mathrm{C}_{2} \times \mathbf{T}_{2}$ & 45.0 & 8.3 & 44.3 & 7.3 & 44.7 & 7.80 \\
\hline $\mathbf{C}_{3} \times \mathbf{T}_{2}$ & 86.7 & 8.2 & 93.3 & 8.3 & 90.0 & 8.25 \\
\hline $\mathrm{C}_{1} \times \mathrm{T}_{3}$ & 67.7 & 8.7 & 68.0 & 8.3 & 67.8 & 8.50 \\
\hline $\mathrm{C}_{2} \times \mathbf{T}_{3}$ & 55.0 & 8.5 & 63.7 & 7.7 & 59.3 & 8.10 \\
\hline $\mathbf{C}_{\mathbf{3}} \times \mathbf{T}_{\mathbf{3}}$ & 88.3 & 8.5 & 95.3 & 8.3 & 91.8 & 8.40 \\
\hline $\mathrm{C}_{1} \times \mathrm{T}_{4}$ & 48.3 & 9.5 & 65.7 & 11.3 & 63.7 & 10.40 \\
\hline $\mathrm{C}_{2} \times \mathbf{T}_{4}$ & 44.5 & 8.0 & 46.7 & 9.3 & 45.6 & 8.65 \\
\hline $\mathrm{C}_{3} \times \mathrm{T}_{4}$ & 86.7 & 8.8 & 91.3 & 8.3 & 89.0 & 8.55 \\
\hline Average & 65.6 & 8.7 & 70.5 & 8.9 & 68.1 & 8.8 \\
\hline LSD at $5 \%$ & 9.0 & 0.95 & 7.2 & 1.1 & 5.0 & 0.8 \\
\hline CV & $9.82 \%$ & $9.64 \%$ & $7.09 \%$ & $9.37 \%$ & $7.68 \%$ & $9.36 \%$ \\
\hline
\end{tabular}

*cutting intervales: $\mathrm{C}_{1}=$ at 50 days, $\mathrm{C}_{2}=$ at 75 days, and $\mathrm{C}_{3}=$ at harvest

**Intercropping systems $: \mathbf{T}_{1}=\mathbf{1 0 0} \%$ barley $+\mathbf{2 5 \%}$ fahl berseem.

$\mathrm{T}_{2}=100 \%$ barley $+50 \%$ fahl berseem. $\mathrm{T}_{3}=100 \%$ barley $+\mathbf{7 5} \%$ fahl berseem and $\mathrm{T}_{4}=100 \%$ barley (sole seeding).

Shendy (2015) showed that the cutting treatment (without and one cut)had significant effect on the number of spikes $\mathrm{m}^{2}, 1000$ kernels weight $(\mathrm{g})$, number of kernels spike ${ }^{-1}$, kernels weight $(\mathrm{g})$,straw yield $\left(\mathrm{t} \mathrm{fed}^{-1}\right)$ grain yield $\left(\mathrm{t} \mathrm{fed}^{-1}\right)$ and protein contents $(\%)$. The intercropping system showed significant differences in the number of kernels Spike ${ }^{-1}$, spike kernels weight and 1000-kernels weight $T_{3}$ gave the highest number of kernels spike ${ }^{-1}$ with an average of (51.8 and 46.03), spike kernels weight with an average of (3.01 and 5.38g) and 1000-kernel weight with an average of $(59.1 \mathrm{~g}$ and $59.8 \mathrm{~g})$ in the $1^{\text {st }}$ and $2^{\text {nd }}$ season respectively. These results are in agreement with those of Shendy (2015).

Number of kernels spike ${ }^{-1}$, spike kernels weight and 1000-kernels weight were significantly influenced by the interaction of cutting intervals and intercropping system in both seasons.
$\left(\mathrm{C}_{3} \times \mathrm{T}_{3}\right)$ gave the highest number of kernels spike $^{-1}$ with an average (65.7 and 66.7) in $2013 / 2014$ and $2014 / 2015$. Also $\left(C_{3} \times T_{3}\right)$ gave the heaviest kernel weight (3.56 and 5.60) in the $1^{\text {st }}$ and $2^{\text {nd }}$ season respectively. For $1000-$ kernel weight, $\left(\mathrm{C}_{3} \times \mathrm{T}_{3}\right)$ gave the heaviest 1000- kernel weight (61.2 and 59.3) in the $1^{\text {st }}$ and $2^{\text {nd }}$ season respectively.

These results are in agreement with, Abou - Kerisha et al., (1996) who showed that sowing $25 \%$ fahl berseem plus $75 \%$ barely gave the highest number of kernels ${ }^{-1}$ spike and kernels weight spike $^{-1}$. While, $50 \%$ fahl berseem plus $50 \%$ barley gave the highest 1000 -kernal weight. The combined analyses over the two seasons showed that the highest value of the number of grains spike $^{-1}$ (66.20), spike kernels weight (4.58g) and 1000-kernel weight $(60.3 \mathrm{~g})$ were produced from $\left(\mathrm{C}_{3} \times \mathrm{T}_{3}\right)$. 
Table (3): Average of no. grains /spike (K/SP), spike kernel weight (SKW), and 1000 kernels weight (100KW) of barley as affected by cutting interval and intercropping system and their interaction in 2013/14 and 2014/15 at Giza.

\begin{tabular}{|c|c|c|c|c|c|c|c|c|c|}
\hline \multirow[b]{2}{*}{ Treatments } & \multicolumn{3}{|c|}{ 2013/2014 } & \multicolumn{3}{|c|}{$2014 / 2015$} & \multicolumn{3}{|c|}{ Combine } \\
\hline & $\begin{array}{l}\text { No. of } \\
\text { grains } \\
\text { spike }\end{array}$ & $\begin{array}{c}\text { Spike } \\
\text { kernels } \\
\text { weight }\end{array}$ & $\begin{array}{c}1000 \\
\text { kernels } \\
\text { weight }\end{array}$ & $\begin{array}{l}\text { No. of } \\
\text { grains } \\
\text { spike } \\
\end{array}$ & $\begin{array}{c}\text { Spike } \\
\text { kernels } \\
\text { weight }\end{array}$ & $\begin{array}{c}1000 \\
\text { kernels } \\
\text { weight }\end{array}$ & $\begin{array}{l}\text { No. of } \\
\text { grains } \\
\text { spike } \\
\end{array}$ & $\begin{array}{c}\text { Spike } \\
\text { kernels } \\
\text { weight }\end{array}$ & $\begin{array}{c}1000 \\
\text { kernels } \\
\text { weight }\end{array}$ \\
\hline $\begin{array}{l}\text { Cutting*: } \\
C_{1}\end{array}$ & 51.93 & 2.88 & 57.7 & 48.50 & 5.43 & 57.41 & 50.22 & 4.16 & 57.4 \\
\hline $\mathrm{C}_{2}$ & 41.65 & 2.44 & 57.9 & 47.35 & 5.28 & 54.3 & 44.50 & 3.86 & 56.1 \\
\hline $\mathbf{C}_{3}$ & 58.85 & 3.59 & 61.3 & 53.10 & 5.65 & 59.1 & 55.98 & 4.62 & 60.2 \\
\hline LSD at $5 \%$ & 4.3 & 0.26 & 0.24 & 5.4 & 0.34 & 3.15 & 3.5 & 0.20 & 1.11 \\
\hline $\begin{array}{l}\text { Intercropping } \\
\text { system }^{* * *} \text { : }\end{array}$ & & & & & & & & & \\
\hline $\mathbf{T}_{1}$ & 50.00 & 3.04 & 59.4 & 52.13 & 5.49 & 55.4 & 51.07 & 4.27 & 57.4 \\
\hline $\mathbf{T}_{2}$ & 51.87 & 3.03 & 59.2 & 52.53 & 5.48 & 55.2 & 52.20 & 4.26 & 57.2 \\
\hline $\mathbf{T}_{3}$ & 51.80 & 3.01 & 59.1 & 46.03 & 5.38 & 59.8 & 48.92 & 4.20 & 59.5 \\
\hline $\mathbf{T}_{4}$ & 49.57 & 2.80 & 58.2 & 47.90 & 5.48 & 51.9 & 48.73 & 4.14 & 55.1 \\
\hline LSD at $5 \%$ & 3.8 & 0.23 & 0.13 & 4.4 & 0.26 & 2.11 & 2.7 & 0.16 & 0.9 \\
\hline $\mathrm{C}_{1} \times \mathbf{T}_{1}$ & 53.7 & 3.15 & 58.6 & 55.0 & 5.60 & 57.0 & 54.35 & 4.38 & 57.8 \\
\hline $\mathrm{C}_{2} \times \mathbf{T}_{1}$ & 42.3 & 2.55 & 59.3 & 51.7 & 5.23 & 54.3 & 47.00 & 3.89 & 56.8 \\
\hline $\mathbf{C}_{3} \times \mathbf{T}_{1}$ & 54.0 & 3.51 & 60.2 & 49.7 & 5.63 & 55.0 & 51.85 & 4.57 & 57.6 \\
\hline $\mathbf{C}_{1} \times \mathbf{T}_{2}$ & 56.3 & 3.15 & 57.1 & 52.3 & 5.20 & 53.7 & 54.30 & 4.18 & 55.4 \\
\hline $\mathbf{C}_{2} \times \mathbf{T}_{2}$ & 37.3 & 2.17 & 57.1 & 42.3 & 5.33 & 48.0 & 39.80 & 3.75 & 52.6 \\
\hline $\mathbf{C}_{3} \times \mathbf{T}_{2}$ & 62.0 & 3.77 & 60.5 & 63.0 & 5.90 & 60.0 & 62.50 & 4.84 & 60.3 \\
\hline $\mathbf{C}_{1} \times \mathbf{T}_{3}$ & 49.0 & 2.75 & 56.9 & 42.7 & 5.23 & 50.7 & 45.85 & 3.99 & 53.8 \\
\hline $\mathbf{C}_{2} \times \mathbf{T}_{3}$ & 45.7 & 2.71 & 59.1 & 48.7 & 5.30 & 43.3 & 47.20 & 4.01 & 51.2 \\
\hline $\mathbf{C}_{\mathbf{3}} \times \mathbf{T}_{\mathbf{3}}$ & 65.7 & 3.56 & 61.2 & 66.7 & 5.60 & 59.3 & 66.20 & 4.58 & 60.3 \\
\hline $\mathbf{C}_{1} \times \mathbf{T}_{4}$ & 48.7 & 2.45 & 58.2 & 44.0 & 5.70 & 54.0 & 46.35 & 4.08 & 56.1 \\
\hline $\mathrm{C}_{2} \times \mathrm{T}_{4}$ & 41.3 & 2.34 & 55.9 & 46.7 & 5.27 & 44.3 & 44.00 & 3.81 & 50.1 \\
\hline $\mathrm{C}_{3} \times \mathrm{T}_{4}$ & 58.7 & 3.60 & 60.5 & 53.0 & 5.47 & $\mathbf{5 7 . 3}$ & 55.85 & 4.54 & 58.9 \\
\hline Average & 50.81 & 2.97 & 58.7 & 49.7 & 55.0 & 53.1 & 50.2 & 4.4 & 57.9 \\
\hline LSD at $5 \%$ & 6.9 & 0.33 & 3.30 & 5.6 & 2.20 & 4.25 & 6.1 & 0.35 & 2.9 \\
\hline CV & $12.14 \%$ & $12.97 \%$ & $3.67 \%$ & $15.4 \%$ & $7.10 \%$ & $7.10 \%$ & $13.12 \%$ & $8.93 \%$ & $4.91 \%$ \\
\hline
\end{tabular}

\subsubsection{Biological yield $\left(\mathrm{t}\right.$ fed $\left.^{-1}\right)$}

The data in Table (4) showed that the biological yield was significantly affected by cutting intervals $(\mathrm{p} \leq 0.05)$. The highest value of biological yield (12.19 and $\left.11.53 \mathrm{t} \mathrm{fed}^{-1}\right)$ was produced from cutting intervals $\left(\mathrm{C}_{3}\right)$, in the $1^{\text {st }}$ and $2^{\text {nd }}$ seasons respectively. The combined analyses over two seasons showed the highest biological yield $\left(11.86 \mathrm{t} \mathrm{fed}^{-1}\right)$, which was produced from cutting intervals $\left(\mathrm{C}_{3}\right)$. The intercropping system showed significant differences in the biological yield; $\left(T_{1}\right)$ gave the highest biological yield with an average of (11.01 and $\left.9.42 \mathrm{t} \mathrm{fed}^{-1}\right)$ in the $1^{\text {st }}$ and $2^{\text {nd }}$ seasons, respectively. Also, it was noticed that $\left(\mathrm{T}_{3}\right)$ gave higher averages of biological yield $\left(10.21 \mathrm{t} \mathrm{fed}^{-1}\right)$ in combined analysis over the two seasons. The interaction effect between cutting intervals $\mathrm{x}$ intercropping systems was significant $\left(\mathrm{C}_{3} \times \mathrm{T}_{3}\right)$ produced the highest value of the biological of yield 11.78 and $11.48 \mathrm{t} \mathrm{fed}^{-1}$, in the $1^{\text {st }}$ and $2^{\text {nd }}$ seasons respectively. The combined analyses over two seasons showed that the highest value of the biological yield (11.63 t $\left.\mathrm{fed}^{-1}\right)$ was produced from $\left(\mathrm{C}_{3} \mathrm{xT}_{3}\right)$. These findings are in agreement with those of Sara et al. (2014) and Abou - Kerisha et al., (1996).

\subsubsection{Grain Yield $\left(t_{\text {fed }}{ }^{-1}\right)$}

The data in Table (4) showed significant differences among cutting intervals and intercropping system as well as the interaction between cutting intervals and intercropping system of grain yield in 2013/2014 and $2014 / 2015$. Grain yield gave $(3.54$ and $3.40 \mathrm{t}$ fed $\left.^{-1}\right)$ with cutting intervals $\left(\mathrm{C}_{3}\right)$,in the $1^{\text {st }}$ and $2^{\text {nd }}$ season respectively. As combined over two seasons, the highest grain yield $\left(3.47 \mathrm{t} \mathrm{fed}^{-1}\right)$ was also produced from cutting intervals $\left(\mathrm{C}_{3}\right)$. These findings are in agreement with those of Shendy (2015). 
Table (4): Average of biological yield (BY), grain yield (GY) and straw yield (SY) of barley as affected by cutting interval, intercropping system and their interaction in 2013/14 and 2014/15 at Giza.

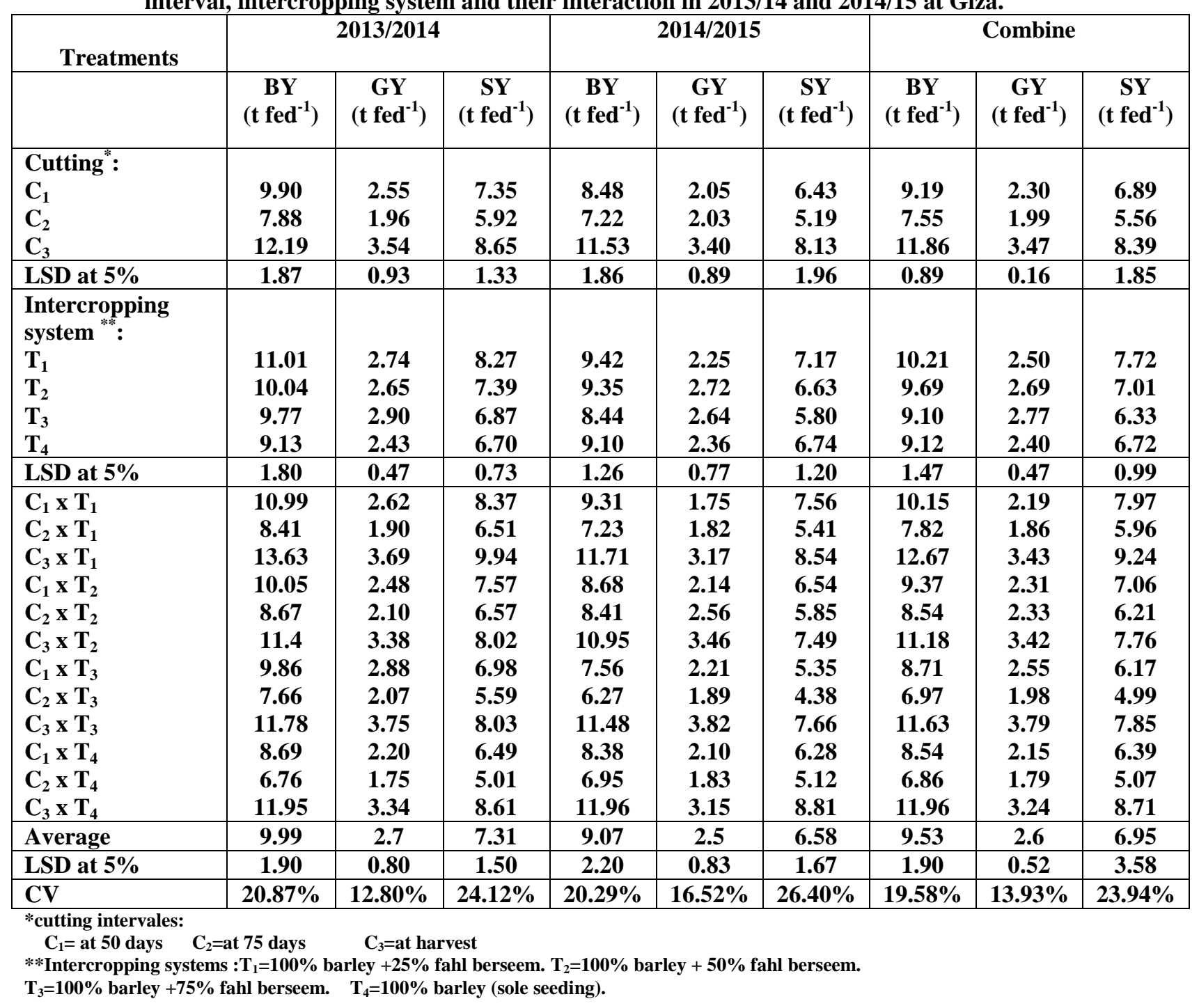

The intercropping system showed significant differences in grain yield. T3 gave the highest grain yield with an average of (2.90 and $2.64 \mathrm{t} \mathrm{fed}^{-1}$ ) in the $1^{\text {st }}$ and $2^{\text {nd }}$ seasons, respectively. $\left(\mathrm{T}_{3}\right)$ gave the highest grain yield (2.77 $\left.\mathrm{t} \mathrm{fed}^{-1}\right)$ in combined analysis over the two seasons. The interaction effect between cutting intervals and intercropping system was highly significant $\left(\mathrm{C}_{3} \mathrm{x} \mathrm{T}_{3}\right)$ produced the highest value of grain yield( 3.75 and $\left.3.82 \mathrm{t} \mathrm{fed}^{-1}\right)$, in the $1^{\text {st }}$ and $2^{\text {nd }}$ season respectively. $\left(\mathrm{C}_{3} \times \mathrm{T}_{3}\right)$ gave the highest grain yield with an average of $\left(3.79 \mathrm{t} \mathrm{fed}^{-1}\right)$ in combined analysis over the two seasons. Similar results were obtained Sara et al., (2014) and Abou-kerish et al.,(1996).

\subsubsection{Straw Yield $\left(\mathrm{t} \mathrm{fed}^{-1}\right)$}

Data presented in Table (4) revealed high significant differences among cutting intervals and intercropping systems as well as the interaction between them for straw yield in
2013/2014 and 2014/2015 seasons. Straw yield gave ( 8.65 and $8.13 \mathrm{t} \mathrm{fed}^{-1}$ ) with cutting intervals $\left(\mathrm{C}_{3}\right)$ in the $1^{\text {st }}$ and $2^{\text {nd }}$ season respectively. As an average over the two seasons, cutting intervals gave the highest straw yield $\left(15.76 \mathrm{t} \mathrm{fed}^{-1}\right)$.

The intercropping system showed significant differences in straw yield; (T1) gave the highest straw yield with an average of (8.27 and $7.17 \mathrm{t} \mathrm{fed}^{-1}$ ) in the $1^{\text {st }}$ and $2^{\text {nd }}$ season respectively. Intercropping system (T3) gave the highest straw yield (7.72 $\left.\mathrm{t} \mathrm{fed}^{-1}\right)$ in combined analyses across the two seasons.

Interaction effect between cutting intervals and intercropping system was highly significant. Cutting intervals $x$ intercropping system $\left(\mathrm{C}_{3} \mathrm{x}\right.$ $\mathrm{T}_{1}$ ) produced the highest values of straw yield (9.94 and $8.54 \mathrm{t} \mathrm{fed}^{-1}$ ) in the $1^{\text {st }}$ and $2^{\text {nd }}$ season respectively. Also cutting intervals $\mathrm{x}$ intercropping system $\left(\mathrm{C}_{3} \mathrm{xT}_{1}\right)$ produced the highest value of straw yield $\left(9.24 \mathrm{tfed}^{-1}\right)$ in 
combined analysis over the two seasons. These results are in agreement with those of Shendy (2015 and Sara et al., (2014) and Abou- Kerisha et al ., (1996).

\subsubsection{Barley fresh and dry forage yield}

Data in Table (5) show the means of fresh and dry yield in 2013/2014 and 2014/2015. Effect of different cutting intervals on fresh and dry was significantly affected by the cutting intervals. Cutting at 75 days $\left(\mathrm{C}_{2}\right)$ gave the highest values for fresh yield $(9.12$ and $7.04 \mathrm{t}$ $\left.\mathrm{fed}^{-1}\right)$ and dry forage (1.77 and $\left.1.44 \mathrm{t} \mathrm{fed}^{-1}\right)$ in the $1^{s t}$ and $2^{\text {nd }}$ seasons, respectively. for fresh forage and $\left(1.36\right.$ and $\left.0.97 \mathrm{t} \mathrm{fed}^{-1}\right)$ for dry yields were obtained from use $\left(\mathrm{C}_{2} \times \mathrm{T}_{2}\right)$ in the $1^{\text {st }}$ and $2^{\text {nd }}$ seasons, respectively.

The combined analysis over the two seasons showed significant effects for the interaction of cutting and intervals $\mathrm{x}$ intercropping system, the highest fresh and dry yield were produced by $\left(\mathrm{C}_{2}\right.$ $\mathrm{x} \mathrm{T}_{2}$ ).

Abou - Kresha et al., (1996) showed that the highest fresh, dry and crude protein yields was obtained from Siko barely variety at $50 \%$ barley. Also, mixing fahl with $25 \%$ barley $50 \%$ and $75 \%$ barley gave 80,56 And $26 \%$ of seed yield

Table (5): Average of fresh and dry yield of barley as affected by cutting interval, intercropping system and their interaction in 2013/14 and 2 014/15 at Giza.

\begin{tabular}{|c|c|c|c|c|c|c|}
\hline \multirow[b]{2}{*}{ Treatments } & \multicolumn{3}{|c|}{ Fresh yield $\left(\mathrm{t}\right.$ fed $\left.^{-1}\right)$} & \multicolumn{3}{|c|}{ Dry yield $\left(\mathbf{t}\right.$ fed $\left.^{-1}\right)$} \\
\hline & 2013/14 & $2014 / 15$ & Combine & 2013/14 & 2014/15 & Combine \\
\hline Cutting*: & & & & & & \\
\hline $\mathrm{C}_{1}$ & 4.56 & 4.66 & 4.61 & 0.80 & 0.85 & 0.83 \\
\hline $\mathrm{C}_{2}$ & 9.12 & 7.04 & 8.08 & 1.77 & 1.44 & 1.60 \\
\hline $\mathbf{C}_{3}$ & --- & --.- & --- & $-\cdots$ & $-\cdots$ & $-\cdots$ \\
\hline LSD at $5 \%$ & 2.0 & 1.46 & 1.94 & 0.33 & 0.84 & 0.50 \\
\hline $\begin{array}{l}\text { Intercropping } \\
\text { system **: }\end{array}$ & & & & & & \\
\hline $\mathrm{T}_{1}$ & 5.08 & 4.93 & 5.00 & 0.99 & 0.95 & 0.97 \\
\hline $\mathbf{T}_{2}$ & 5.92 & 4.50 & 5.21 & 1.06 & 0.97 & 1.06 \\
\hline $\mathbf{T}_{3}$ & 5.07 & 4.63 & 4.85 & 0.93 & 0.91 & 0.92 \\
\hline$T_{4}$ & 7.36 & 6.04 & 6.70 & 1.38 & 1.19 & 1.28 \\
\hline LSD at 5\% & 1.2 & 1.32 & 1.50 & 0.23 & 0.54 & 0.44 \\
\hline$C_{1} \times T_{1}$ & 4.05 & 4.55 & 4.30 & 0.75 & 0.83 & 0.79 \\
\hline $\mathrm{C}_{2} \times \mathrm{T}_{1}$ & 6.08 & 5.32 & 5.70 & 1.23 & 1.07 & 1.15 \\
\hline $\mathrm{C}_{3} \times \mathrm{T}_{1}$ & --- & --- & --- & --- & --- & --- \\
\hline$C_{1} \times T_{2}$ & 4.50 & 4.52 & 4.51 & 0.75 & 0.83 & 0.79 \\
\hline $\mathbf{C}_{2} \times \mathbf{T}_{2}$ & 7.33 & 4.67 & 5.20 & 1.36 & 0.97 & 1.13 \\
\hline $\mathbf{C}_{3} \times \mathbf{T}_{2}$ & ---- & ---- & ---- & --- & ---- & --- \\
\hline$C_{1} \times T_{3}$ & 4.20 & 4.78 & 4.49 & 0.73 & 0.88 & 0.80 \\
\hline $\mathbf{C}_{2} \times \mathbf{T}_{3}$ & 5.85 & 4.57 & 5.21 & 1.12 & 0.95 & 1.04 \\
\hline $\mathbf{C}_{3} \times \mathbf{T}_{3}$ & ---- & ---- & ---- & --- & ---- & ---- \\
\hline $\mathrm{C}_{1} \times \mathrm{T}_{4}$ & 5.82 & 4.78 & 5.30 & 1.03 & 0.89 & 0.96 \\
\hline $\mathbf{C}_{2} \times \mathbf{T}_{4}$ & 8.91 & 7.29 & 8.10 & 1.74 & 1.51 & 1.62 \\
\hline $\mathrm{C}_{3} \times \mathrm{T}_{4}$ & -.-- & -.-- & --.- & $-\ldots$ & --.- & --.- \\
\hline Average & 5.84 & 5.04 & 5.44 & 1.09 & 0.98 & 1.04 \\
\hline LSD at 5\% & 2.5 & 2.20 & 2.36 & 0.40 & 0.85 & 0.75 \\
\hline CV & $16.11 \%$ & $22.74 \%$ & $19.54 \%$ & $10.1 \%$ & $8.2 \%$ & $8.2 \%$ \\
\hline
\end{tabular}

The intercropping system showed significant differences in fresh and dry yield. $\left(T_{2}\right)$ gave the highest values for fresh forage yield with an average of (5.92 and $\left.4.50 \mathrm{t} \mathrm{fed}^{-1}\right)$ and dry forage 1.06 and 0.97 yield $\left(\mathrm{t} \mathrm{fed}^{-1}\right)$ in the $1^{\text {st }}$ and $2^{\text {nd }}$ seasons, respectively. For the interaction effect of cutting intervals $x$ intercropping system, on fresh and dry yield of barley, the highest values (7.33 and $\left.4.67 \mathrm{t} \mathrm{fed}^{-1}\right)$ of fahl berseem. Similar results were obtained by Abou - Kerisha et al., (1996), and Sara et al., (2014) and Shendy (2015).

\subsection{Agronomic traits of Fahl Berseem \\ 3.2.1. Growth traits}

Data in Table (6) showed the effect of cutting intervals, intercropping system and their interaction in 2013/2014-2014/2015 and it's combined on growth traits (plant height, number 
Table (6): Average of plant height (PH) number of branches per plant (Br/plant) and leaves stem ratio\% (L/St\%) of Fahl berseem as affected by cutting interval, intercropping system and their interaction in 2013/14 and $2014 / 15$ at Giza.

\begin{tabular}{|c|c|c|c|c|c|c|c|c|c|}
\hline \multirow[b]{2}{*}{ Treatments } & \multicolumn{3}{|c|}{$2013 / 2014$} & \multicolumn{3}{|c|}{$2014 / 2015$} & \multicolumn{3}{|c|}{ Combine } \\
\hline & $\begin{array}{l}\text { Pl-Ht } \\
(\mathrm{cm})\end{array}$ & $\begin{array}{c}\text { No. of } \\
\text { Br plant }\end{array}$ & $\begin{array}{c}\mathbf{L} / \mathbf{S t} \\
\%\end{array}$ & $\begin{array}{l}\text { Pl-Ht } \\
\text { (cm) }\end{array}$ & $\begin{array}{c}\text { No. of } \\
\text { Br plant }{ }^{-1}\end{array}$ & $\begin{array}{c}\text { L /St } \\
\text { Ratio } \\
\%\end{array}$ & $\begin{array}{l}\text { Pl-Ht } \\
(\mathrm{cm})\end{array}$ & $\begin{array}{c}\text { No. of } \\
\text { Br } \\
\text { plant }^{-1}\end{array}$ & $\begin{array}{c}\text { L /St } \\
\text { Ratio } \\
\%\end{array}$ \\
\hline $\begin{array}{l}\text { Cutting: } \\
\mathrm{C}_{1}\end{array}$ & 78.83 & 4.33 & 22.64 & 69.08 & 4.80 & 21.79 & 73.96 & 4.57 & 23.25 \\
\hline $\mathrm{C}_{2}$ & 87.59 & 4.82 & 22.34 & 76.35 & 5.03 & 22.65 & 81.97 & 4.93 & 22.50 \\
\hline $\mathrm{C}_{3}$ & 87.57 & 6.45 & 23.86 & 83.14 & 6.79 & 22.03 & 85.36 & 6.62 & 22.94 \\
\hline LSD at $5 \%$ & 5.54 & 0.25 & 1.0 & 7.98 & 0.62 & 0.97 & 4.04 & 0.28 & 0.93 \\
\hline $\begin{array}{l}\text { Intercrop system: } \\
T_{1}\end{array}$ & 75.50 & 5.41 & 23.03 & 71.53 & 6.00 & 22.17 & 73.52 & 5.71 & 22.60 \\
\hline $\mathbf{T}_{2}$ & 79.81 & 4.62 & 22.83 & 72.20 & 5.09 & 22.10 & 76.01 & 4.86 & 22.47 \\
\hline $\mathbf{T}_{3}$ & 81.48 & 4.49 & 22.74 & 74.83 & 4.83 & 22.09 & 78.16 & 4.66 & 22.42 \\
\hline $\mathbf{T}_{4}$ & 95.20 & 6.32 & 23.18 & 86.18 & 6.25 & 22.30 & 90.69 & 6.29 & 22.74 \\
\hline LSD at $5 \%$ & 3.59 & 0.21 & 0.78 & 5.62 & 0.38 & 0.68 & 3.20 & 0.23 & 0.68 \\
\hline $\mathrm{C}_{1} \times \mathrm{T}_{1}$ & 65.50 & 4.77 & 22.63 & 65.50 & 5.43 & 22.03 & 65.50 & 5.10 & 22.33 \\
\hline $\mathrm{C}_{2} \times \mathrm{T}_{1}$ & 84.40 & 5.03 & 22.57 & 72.50 & 5.50 & 21.77 & 78.45 & 5.27 & 22.17 \\
\hline $\mathrm{C}_{3} \times \mathrm{T}_{1}$ & 76.60 & 6.43 & 23.90 & 76.60 & 7.07 & 22.70 & 76.60 & 6.75 & 23.30 \\
\hline $\mathrm{C}_{1} \times \mathrm{T}_{2}$ & 76.47 & 3.73 & 22.63 & 65.57 & 4.17 & 22.50 & 71.02 & 3.95 & 22.33 \\
\hline $\mathbf{C}_{2} \times \mathbf{T}_{2}$ & 85.03 & 4.10 & 22.10 & 73.20 & 4.50 & 21.77 & 79.12 & 4.30 & 21.93 \\
\hline $\mathbf{C}_{3} \times \mathbf{T}_{2}$ & 77.93 & 6.03 & 23.77 & 77.83 & 6.60 & 22.50 & 77.88 & 6.32 & 23.13 \\
\hline $\mathrm{C}_{1} \times \mathrm{T}_{3}$ & 78.13 & 3.80 & 22.57 & 69.50 & 4.13 & 22.03 & 73.82 & 3.97 & 23.10 \\
\hline $\mathbf{C}_{2} \times \mathbf{T}_{3}$ & 86.80 & 3.83 & 21.97 & 75.90 & 4.17 & 21.77 & 81.35 & 4.00 & 21.87 \\
\hline $\mathrm{C}_{\mathbf{3}} \times \mathbf{T}_{\mathbf{3}}$ & 79.50 & 5.83 & 23.70 & 79.10 & 6.20 & 22.00 & 79.30 & 6.02 & 22.28 \\
\hline $\mathrm{C}_{1} \times \mathrm{T}_{5}$ & 95.20 & 5.01 & 22.75 & 75.76 & 5.50 & 22.11 & 85.48 & 5.26 & 22.43 \\
\hline $\mathrm{C}_{2} \times \mathrm{T}_{5}$ & 94.16 & 6.40 & 22.75 & 83.73 & 5.94 & 21.88 & 88.95 & 6.17 & 22.32 \\
\hline $\mathbf{C}_{3} \times \mathbf{T}_{5}$ & 96.24 & 7.55 & 24.04 & 99.06 & 7.31 & 22.91 & 97.65 & 7.43 & 23.48 \\
\hline Average & 83.00 & 5.21 & 22.95 & 76.19 & 5.54 & 22.16 & 79.59 & 5.38 & 22.56 \\
\hline LSD at $5 \%$ & 6.22 & 0.36 & 1.04 & 9.73 & 0.66 & 1.02 & 5.47 & 0.36 & 1.01 \\
\hline CV\% & 4.43 & 4.24 & 4.26 & 7.51 & 6.98 & 7.41 & 6.05 & 5.90 & 6.00 \\
\hline
\end{tabular}

*cutting intervales:

$\mathrm{C}_{1}=$ at 50 days $\mathrm{C}_{2}=$ at 75 days $\quad \mathrm{C}_{3}=$ at harvest

**Intercropping systems : $\mathrm{T}_{1}=\mathbf{1 0 0} \%$ barley $+\mathbf{2 5} \%$ fahl berseem. $\quad \mathrm{T}_{2}=\mathbf{1 0 0 \%}$ barley $+\mathbf{5 0} \%$ fahl berseem.

$T_{3}=100 \%$ barley $+75 \%$ fahl berseem. $\quad T_{4}=100 \%$ barley (sole seeding).

of branches plant ${ }^{-1}$ and leaf/stem ratio). Cutting intervals showed a significant effect on plant height, the number of branches/plant and leaves/stem ratio. The results showed that the highest plant height $(87.57$ and $83.14 \mathrm{~cm})$, no. of branches plant ${ }^{-1}$ (6.45 and 6.79) were recorded by cutting intervals $\left(\mathrm{C}_{3}\right)$, as well as, from leaf stem ratio \% (23.86 and 22.03) with increasing cutting interval in the $1^{\text {st }}$ and the $2^{\text {nd }}$ seasons, respectively.

The intercropping system showed significant differences for plant height, the number of branches plant ${ }^{-1}$ except leaves stem ${ }^{-1}$ ratio traits among different intercropping system. The results showed that the highest plant height was recorded by intercropping system $\left(\mathrm{T}_{3}\right)$. It gave $(81.48$ and $74.83 \mathrm{~cm})$ whereas, $\left(\mathrm{T}_{1}\right)$ gave no. of branches plant ${ }^{-1}$ (5.41 and 6.00) and leaf stem ratio\% (23.03 and 22.17) in the $1^{\text {st }}$ and $2^{\text {nd }}$ seasons, respectively. For the interaction effect of cutting intervals $\mathrm{x}$ intercropping treatments on growth traits, the highest values for plant height, number of branches plant ${ }^{-1}$ and leaves stem ${ }^{-1}$ ratio traits were obtained from $\left(\mathrm{C}_{3} \times \mathrm{T}_{3}\right)$ in $1^{\text {st }}$ and $2^{\text {nd }}$ seasons. The combined analysis over the two seasons showed significant effects for the interaction of plant height, the number of branches plant ${ }^{-1}$ and leaves stem $^{-1}$ ratio caused by $\left(\mathrm{C}_{3} \times \mathrm{T}_{3}\right)$. These findings are in harmony with Abd El-Gawad, (1993), Haggag et al.,( 1995) and Abdel-Zaher et al., 2009.

\subsubsection{Fresh and dry forage yield}

Data presented in Table (7) show the means of fresh and dry forage yield in 2013/2014 and 2014/2015. Cutting intervals showed a significant effect on fresh and dry forage yield. The results showed that the highest fresh yield was recorded by cutting intervals $\left(\mathrm{C}_{2}\right)$ gave $(4.55$ 
and $\left.4.54 \mathrm{t} \mathrm{fed}^{-1}\right)$ and dry forage yield (0.89 and $0.87 \mathrm{t} \mathrm{fed}^{-1}$ ) in the $1^{\text {st }}$ and the $2^{\text {nd }}$ seasons respectively.

The intercropping system showed a significant difference on fresh and dry forage yield among different intercropping system. The results showed that the highest value of fresh yield were recorded by intercropping system $\left(T_{3}\right)$ gave dry forage yield (3.99 and $\left.3.41 \mathrm{t} \mathrm{fed}^{-1}\right)$ and dry yield $\left(0.65\right.$ and $\left.0.66 t \mathrm{fed}^{-1}\right)$ in the $1^{\text {st }}$ and $2^{\text {nd }}$ seasons, respectively. The interaction effects between cutting intervals $\mathrm{x}$ intercropping system were significant in the $1^{\text {st }}$ and $2^{\text {nd }}$ seasons, $\left(\mathrm{C}_{2} \mathrm{X}\right.$ $\mathrm{T}_{3}$ ) produced the highest value of fresh yield forage yield (3.7 and $3.7 \mathrm{t} \mathrm{fed}^{-1}$ ) and dry yield $\left(0.71\right.$ and $\left.0.81 \mathrm{t} \mathrm{fed}^{-1}\right)$ in the $1^{\text {st }}$ and $2^{\text {nd }}$ season respectively. The combined analysis over the two seasons showed significant effects for the interaction by $\left(\mathrm{C}_{2} \times \mathrm{T}_{3}\right)$ from fresh and dry yield.

Effect of different cutting intervals on these traits indicated that increase of cutting intervals caused an increase of plant height and the number of branches/plant ${ }^{-1}$ except leaves stem ratio \%. This result may be due to the long period of growth for accumulated forage yield. Whereas, harvest day interval was the best interval for all growth traits at the two season and combined. These increases seem to be attributed to increasing yield components i.e. plant height, leaves/stem ratio and the number of branches. These results are in agreement with Nor EL-Din et al., (1984) and Abdel-Gawad (1993).

The obtained results revealed that barley is a crop which can be used as a sole crop or in mixture system with fahl berseem, but it is important to determine cutting interval, which produce the greatest forage yield and grain yield from barley. On the other hand, growth habit of berseem in mixture treatments was less than pure stand, indicating the great competition resulting from barley plants shading effects, as well as the effect of intra specific competition among berseem plants, when intercropping pattern

Table (7): Average of fresh yield t/fed (FY), dry yield T/fed (DY), seed yield Kg/fed (SY) and hay yield t/fed (HY) of Fahl berseem as affected by cutting interval, intercropping system and their interaction in 2013/14 and 2014/15 at Giza.

\begin{tabular}{|c|c|c|c|c|c|c|c|c|c|c|c|c|}
\hline \multirow[b]{2}{*}{ Treatments } & \multicolumn{4}{|c|}{$2013 / 2014$} & \multicolumn{4}{|c|}{$2014 / 2015$} & \multicolumn{4}{|c|}{ Combine } \\
\hline & $\begin{array}{l}\text { fresh } \\
\text { yield } \\
\text { t fed }^{-1}\end{array}$ & $\begin{array}{c}\text { dry } \\
\text { yield } \\
\text { t fed }^{-1}\end{array}$ & $\begin{array}{l}\text { seed } \\
\text { yield } \\
\mathrm{t}_{\text {fed }}{ }^{-1}\end{array}$ & $\begin{array}{c}\text { Stra } \\
w \\
\text { yield } \\
t \text { fed } \\
1\end{array}$ & $\begin{array}{l}\text { fresh } \\
\text { yield } \\
t_{\text {fed }}{ }^{-1}\end{array}$ & $\begin{array}{c}\text { dry } \\
\text { yield } \\
\text { t fed }^{-1}\end{array}$ & $\begin{array}{c}\text { seed } \\
\text { yield } \\
\text { t fed }^{-1}\end{array}$ & $\begin{array}{l}\text { Straw } \\
\text { yield } \\
\mathbf{t}^{\text {fed }}{ }^{-1}\end{array}$ & $\begin{array}{l}\text { fresh } \\
\text { yield } \\
\text { t fed }^{-1}\end{array}$ & $\begin{array}{c}\text { dry } \\
\text { yield } \\
\text { t fed }^{-1}\end{array}$ & $\begin{array}{l}\text { seed } \\
\text { yield } \\
t_{\text { fed }}^{-1}\end{array}$ & $\begin{array}{c}\text { Straw } \\
\text { yield } \\
\text { t fed }^{-1}\end{array}$ \\
\hline $\begin{array}{l}\text { Cutting: } \\
\mathrm{C}_{1} \\
\mathrm{C}_{2} \\
\mathrm{C}_{3}\end{array}$ & $\begin{array}{c}2.82 \\
4.55 \\
--- \\
\end{array}$ & $\begin{array}{c}0.49 \\
0.89 \\
--- \\
\end{array}$ & $\begin{array}{c}--- \\
--- \\
0.226\end{array}$ & $\begin{array}{c}--- \\
--- \\
2.12\end{array}$ & $\begin{array}{c}2.90 \\
4.54 \\
--- \\
\end{array}$ & $\begin{array}{c}0.54 \\
0.87 \\
--- \\
\end{array}$ & $\begin{array}{c}---- \\
--- \\
0.227\end{array}$ & $\begin{array}{c}--- \\
--. \\
2.24\end{array}$ & $\begin{array}{l}2.86 \\
4.80 \\
--- \\
\end{array}$ & $\begin{array}{c}0.51 \\
0.88 \\
--- \\
\end{array}$ & $\begin{array}{c}---- \\
--- \\
0.226\end{array}$ & $\begin{array}{l}---- \\
--- \\
2.18\end{array}$ \\
\hline LSD 5\% & 1.63 & 0.01 & --- & -- & 1.37 & 0.01 & -- & --- & 1.41 & 0.02 & $-\cdots$ & --- \\
\hline $\begin{array}{l}\text { Intercropping } \\
\text { system: } \\
\mathbf{T}_{1} \\
\mathbf{T}_{2} \\
\mathbf{T}_{3} \\
\mathbf{T}_{4}\end{array}$ & $\begin{array}{l}1.67 \\
3.20 \\
3.99 \\
7.30\end{array}$ & $\begin{array}{l}0.32 \\
0.56 \\
0.65 \\
1.36\end{array}$ & $\begin{array}{l}0.106 \\
0.127 \\
0.302 \\
0.368\end{array}$ & $\begin{array}{l}1.84 \\
1.98 \\
2.23 \\
2.41 \\
\end{array}$ & $\begin{array}{l}1.63 \\
3.20 \\
3.41 \\
7.70 \\
\end{array}$ & $\begin{array}{l}0.30 \\
0.62 \\
0.66 \\
1.48 \\
\end{array}$ & $\begin{array}{l}0.103 \\
0.125 \\
0.319 \\
0.357\end{array}$ & $\begin{array}{l}1.91 \\
2.00 \\
2.37 \\
2.69\end{array}$ & \begin{tabular}{|l|l|}
1.63 & \\
3.21 & 3.01 \\
7.68 & \\
\end{tabular} & $\begin{array}{l}0.31 \\
0.59 \\
0.65 \\
1.42 \\
\end{array}$ & $\begin{array}{l}0.105 \\
0.126 \\
0.310 \\
0.362\end{array}$ & $\begin{array}{l}1.88 \\
1.99 \\
2.30 \\
2.55\end{array}$ \\
\hline LSD 5\% & 1.63 & 0.01 & 21.6 & 0.13 & 1.37 & 0.26 & 0.02 & 0.12 & 1.41 & 0.24 & 21.43 & 0.11 \\
\hline $\begin{array}{l}\mathbf{C}_{1} \times \mathbf{T}_{1} \\
\mathrm{C}_{2} \times \mathrm{T}_{1}\end{array}$ & $\begin{array}{l}1.29 \\
2.05\end{array}$ & $\begin{array}{l}0.24 \\
0.42\end{array}$ & --- & --- & $\begin{array}{l}1.31 \\
1.95\end{array}$ & $\begin{array}{l}0.24 \\
0.37\end{array}$ & --- & --- & $\begin{array}{l}1.31 \\
1.95\end{array}$ & $\begin{array}{l}0.24 \\
0.37\end{array}$ & ---- & --- \\
\hline$C_{3} \times T_{1}$ & -.- & --- & 0.106 & 1.84 & --.- & --- & 0.103 & 1.91 & -.-- & --.- & 0.105 & 1.88 \\
\hline$C_{1} \times T_{2}$ & 2.69 & 0.45 & ---- & --- & 2.71 & 0.52 & ---- & ---- & 2.71 & 0.52 & ---- & ---- \\
\hline $\mathbf{C}_{2} \times \mathbf{T}_{2}$ & 3.70 & 0.69 & --- & --- & 3.70 & 0.71 & --- & --- & 3.70 & 0.71 & --- & --- \\
\hline$C_{3} \times T_{2}$ & --- & ---- & 0.127 & 1.98 & --- & --- & 0.125 & 2.00 & --- & --- & 0.126 & 1.99 \\
\hline$C_{1} \times T_{3}$ & 2.29 & 0.39 & ---- & --- & 2.31 & 0.43 & ---- & ---- & 2.31 & 0.43 & ---- & ---- \\
\hline $\mathrm{C}_{2} \times \mathrm{T}_{3}$ & 3.70 & 0.71 & --- & --- & 3.70 & 0.81 & ---- & --- & 3.70 & 0.81 & --- & --- \\
\hline $\mathrm{C}_{3} \times \mathrm{T}_{3}$ & ---- & --- & 0.302 & 2.23 & --- & --- & 0.319 & 2.37 & ---- & ---- & 0.310 & 2.30 \\
\hline$C_{1} \times T_{5}$ & 5.10 & 0.89 & --- & --- & 5.50 & 1.03 & ---- & --.- & 5.30 & 1.03 & ---- & --- \\
\hline$C_{2} \times T_{5}$ & 9.54 & 0.88 & ---- & ---- & 9.86 & 1.94 & ---- & ---- & 9.66 & 1.94 & ---- & ---- \\
\hline $\mathrm{C}_{3} \times \mathrm{T}_{5}$ & $\cdots$ & $\cdots$ & 0.368 & 2.41 & --- & --- & 0.357 & 2.69 & -.- & --- & 0.362 & 2.55 \\
\hline Average & 3.80 & 0.58 & 0.23 & 2.12 & 7.68 & 0.76 & 0.23 & 2.24 & 3.88 & 0.76 & 0.23 & 2.18 \\
\hline LSD at $5 \%$ & 0.66 & 0.04 & ---- & ---- & 1.43 & 0.34 & ----- & ------ & 1.52 & 0.30 & ---- & ---- \\
\hline CV\% & 6.18 & 9.12 & --- & ---- & 6.23 & 9.1 & ---- & ----- & 7.89 & 7.91 & --- & --- \\
\hline
\end{tabular}


(100\% barley $+75 \%$ berseem) comparing with its sole stand. These results are agreement with those obtained by (Abou-Kerisha et al. 1996).

\subsubsection{Seed and straw yields of fahl berseem}

Data presented in Table (7) show the effect of cutting intervals and intercropping system on seed and straw yield. Fahl berseem only produced seed yield at cutting intervals $\left(\mathrm{C}_{3}\right)$ gave $\left(0.226\right.$ and $\left.0.227 \mathrm{t} \mathrm{fed}^{-1}\right)$ and straw yield (2.12 and $\left.2.24 \mathrm{t} \mathrm{fed}^{-1}\right)$ in the $1^{\text {st }}$ and $2^{\text {nd }}$ season respectively. The intercropping system gave, significant differences for seed and straw yield traits among different intercropping systems. The results showed that the highest seed yield was recorded by intercropping system $\left(\mathrm{T}_{3}\right)$ gave $\left(0.302\right.$ and $\left.0.319 \mathrm{t} \mathrm{fed}^{-1}\right)$ and straw yield $(2.23$ and $2.37 \mathrm{t} \mathrm{fed}^{-1}$ ) in the $1^{\text {st }}$ and $2^{\text {nd }}$ seasons, respectively. The combined mean over the two seasons showed that $\left(T_{3}\right)$ gave the highest values of seed and straw yield. Seed of the Fahl berseem could be produced by inter seeding with grain barley. However, seed yield slightly decreased in this case. In contrast, seed yield of pure fahl berseem is higher than fahl berseem sown in mixture with barley. These results were in agreement with Radwan et al., (1983) and Abel-Zaher et al., (2009).

\subsection{Nutritive value, competitive relationships and benefit advantage of cutting interval and intercropping system}

\subsubsection{Chemical composition and nutritive value}

Data presented in Table (8) revealed significant differences among cutting intervals. Forage quality parameters i.e. crude protein (CP $\%$ ), crude fiber (CF \%), digestible protein (DP $\%$ ), and total digestible nutrients (TDN \%)were significantly affected due to cutting intervals. The highest values of CP\% (13.23), DP\% (8.81), and TDN \% (66.92), resulted from cutting at 50 days $\left(C_{1}\right)$. However, cutting at 75 days $\mathrm{C}_{2}$ ranked after cutting at 50 days $\left(C_{1}\right)$. On the other hand cutting in $\left(\mathrm{C}_{3}\right)$ led to increases in crude fiber percentage ( $\mathrm{CF} \%$ ), where the highest percentage of crude fiber $(25.14 \%)$ produced from period $\left(\mathrm{C}_{3}\right)$. The effect of cutting at harvest $\left(\mathrm{C}_{3}\right)$ during the vegetative and maturity stage may be due to the reduction in photosynthesis which effect dry matter accumulation, which consequently decrease crude protein percentage and increase crude fiber percentage.

The intercropping system percentage had a significant effect on crude protein $(\mathrm{CF} \%)$, crude fiber (C F\%), digestible protein (DP\%), and the total digestible nutrients(TDN\%). The highest percentages of crude protein (12.82\%), digestible protein $(8.43 \%)$, resulted from $\left(\mathrm{T}_{2}\right)$. On the contrary sole fahl berseem recorded the highest percentage of TDN (69.59\%), and crude fiber $\left(\mathrm{T}_{1}\right)$ recorded highest percentage $(25.65 \%)$.

The interaction effect between cutting intervals and intercropping system was significant effect on crude protein (CP), crude fiber (CF), digestible protein (DP), and total digestible nutrients (TDN) percentages. The significance of the interactions indicated that the relative performance of the barley- fahl berseem intercropping was not consistent across cutting interval treatments. These findings are in harmony with Abd El-Gawad (1993), Haggag et al., (1995)

Table (8): Forage quality parameters (crude protein (CP $\%$ ), crude fiber (CF \%), digestible protein (DP $\%$ ), and total digestible nutrients (TDN \%)) as affected by cutting interval, intercropping system and their interaction in 2013/14 and 2014/15 at Giza.

\begin{tabular}{|c|c|c|c|c|}
\hline $\begin{array}{l}\text { Characters } \\
\text { Treatments }\end{array}$ & СР\% & $\mathrm{CF} \%$ & DP\% & $\begin{array}{c}\text { TDN } \\
\%\end{array}$ \\
\hline \multicolumn{5}{|l|}{ A-Cutting intervals } \\
\hline 50 days & 13.23 & 22.79 & 8.81 & 66.92 \\
\hline 75 days & 11.70 & 23.43 & 7.39 & 66.83 \\
\hline At harvest 150 days & 7.96 & 25.14 & 3.91 & 66.43 \\
\hline L.S.D at $5 \%$ & 2.86 & 1.38 & 0.40 & 1.25 \\
\hline \multicolumn{5}{|c|}{ B- Intercropping systems } \\
\hline $100 \% B+25 \% F$ & 8.21 & 25.65 & 4.14 & 65.92 \\
\hline $100 \% \mathrm{~B}+50 \% \mathrm{~F}$ & 12.82 & 23.05 & 8.43 & 66.82 \\
\hline $100 \% \mathrm{~B}+75 \% \mathrm{~F}$ & 10.86 & 25.03 & 6.61 & 65.69 \\
\hline Barley sole crop & 10.80 & 25.16 & 6.55 & 65.60 \\
\hline Berseem sole crop & 12.13 & 20.06 & 7.79 & 69.55 \\
\hline LSD at5 \% & 0.75 & 1.21 & $\mathbf{0 . 7 0}$ & 1.02 \\
\hline C-Interaction: & $*$ & $*$ & $*$ & $*$ \\
\hline
\end{tabular}

\subsubsection{Land equivalent ratio (LER)}

Data presented in Table (9) and indicate the effect of cutting intervals and intercropping system on land equivalent (LER) for combined seasons.

Effect of different cutting intervals on land equivalent (LER) showed that cutting at 50 days $\left(\mathrm{C}_{1}\right)$ gave the highest land usage value (2.48), and the intercropping system, $\mathrm{T}_{3}$ (barley $100 \%+$ (berseem 75\%) gave the highest land usage values (3.12) from land equivalent (LER).

For the interaction effect of cutting intervals $\mathrm{x}$ intercropping system on land equivalent (LER), the highest land usage values 2.47 for land equivalent (LER) were obtained from use $\left(\mathrm{C}_{1} \times \mathrm{T}_{3}\right)$. However, the relative yield (RY) of 
Table (9): Competitive relationships of intercropping pattern with berseem as affected by cutting interval, intercropping system and their interaction in 2013/14 and 2014/15 at Giza (combined analysis).

\begin{tabular}{|c|c|c|c|c|c|c|c|c|c|}
\hline \multirow{3}{*}{ Treatments } & \multicolumn{4}{|c|}{${\text { Yield } \mathbf{t} \text { fed }^{-1}}^{-1}$} & \multicolumn{4}{|c|}{ Relative yield \% } & \multirow{3}{*}{ LER } \\
\hline & \multicolumn{2}{|c|}{ Barley } & \multicolumn{2}{|c|}{ Berseem Fahl } & \multicolumn{2}{|c|}{ Barley } & \multicolumn{2}{|c|}{ Berseem Fahl } & \\
\hline & Grain & Forage & Forage & Seed & Grain & Forage & Forage & Seed & \\
\hline \multicolumn{10}{|l|}{ Cutting intervals: } \\
\hline At 50 days $\quad\left(C_{1}\right)$ & 2.30 & 4.65 & 2.96 & -.-. & 1.07 & 0.88 & 0.54 & --- & 2.48 \\
\hline At 75 days & 1.99 & 6.23 & 4.80 & --.- & 1.11 & 0.77 & 0.49 & -.-- & 2.37 \\
\hline Harvest day $\quad\left(C_{3}\right)$ & 3.43 & --- & --- & 0.23 & 1.06 & --- & --- & 0.62 & 1.68 \\
\hline \multicolumn{10}{|l|}{ Cropping Systems*: } \\
\hline $\begin{array}{l}100 \% \mathrm{~B}+25 \% \mathrm{~F}\left(\mathrm{I}_{1}\right) \\
100 \% \mathrm{~B}+50 \% \mathrm{~F} \quad\left(\mathrm{~T}_{2}\right)\end{array}$ & $\begin{array}{l}2.49 \\
2.69\end{array}$ & $\begin{array}{l}5.00 \\
5.21\end{array}$ & $\begin{array}{l}1.03 \\
3.21\end{array}$ & 0.13 & $\begin{array}{l}1.04 \\
1.12\end{array}$ & $\begin{array}{l}0.15 \\
0.78\end{array}$ & 0.22 & 0.29 & $\begin{array}{l}2.29 \\
2.67\end{array}$ \\
\hline $100 \% \mathrm{~B}+75 \% \mathrm{~F}\left(\mathrm{~T}_{3}\right)$ & 2.72 & 4.85 & 3.01 & 0.31 & 1.14 & 0.72 & 0.40 & 0.86 & 3.12 \\
\hline Solid Barley & 2.39 & 6.70 & ---- & ---- & ---- & 1 & ---- & ---- & 1 \\
\hline Solid Berseem & ---- & ---- & 7.68 & 0.36 & 1 & ---- & 1 & 1 & 1 \\
\hline $\mathbf{C}_{1} \times \mathbf{T}_{1}$ & 2.18 & 4.3 & 1.3 & -.-- & 1.01 & 0.81 & 0.25 & -..- & 2.07 \\
\hline $\mathrm{C}_{2} \times \mathrm{T}_{1}$ & 1.86 & 5.7 & 2.0 & -..- & 1.04 & 0.70 & 0.20 & --- & 1.94 \\
\hline$C_{3} \times T_{1}$ & 3.43 & --- & --- & 0.11 & 1.06 & ---- & ---- & 0.29 & 1.35 \\
\hline $\mathbf{C}_{1} \times \mathbf{T}_{2}$ & 2.31 & 4.5 & 2.7 & --- & 1.07 & 0.85 & 0.51 & --- & 2.44 \\
\hline $\mathrm{C}_{2} \times \mathrm{T}_{2}$ & 2.33 & 5.9 & 3.7 & -..- & 1.30 & 0.73 & 0.38 & ---- & 2.41 \\
\hline $\mathrm{C}_{3} \times \mathbf{T}_{2}$ & 3.42 & --- & --- & 0.13 & 1.06 & --- & --- & 0.35 & 1.40 \\
\hline$C_{1} \times T_{3}$ & 2.55 & 4.5 & 2.3 & ---- & 1.19 & 0.85 & 0.44 & ---- & 2.47 \\
\hline $\mathbf{C}_{2} \times \mathbf{T}_{3}$ & 1.98 & 5.2 & 3.7 & -..- & 1.11 & 0.64 & 0.38 & --- & 2.13 \\
\hline $\mathrm{C}_{3} \times \mathrm{T}_{3}$ & 3.64 & --- & --- & 0.31 & 1.12 & --- & --- & 0.86 & 1.98 \\
\hline$C_{1} \times$ Solid Barley & 2.15 & 5.3 & --- & --- & 1 & 1 & --- & --- & 2 \\
\hline$C_{2} \times$ Solid Barley & 1.79 & 8.1 & --- & --- & 1 & 1 & --- & --- & 2 \\
\hline$C_{3} \times$ Solid Barley & 3.24 & --- & ---- & -.-- & 1 & --- & --- & -.-- & 1 \\
\hline$C_{1} \times$ Solid Berseem & --- & --.- & 5.3 & ---- & --.- & ---- & 1 & --- & 1 \\
\hline$C_{2} \times$ Solid Berseem & --- & --- & 9.7 & --- & --- & --- & 1 & --- & 1 \\
\hline$C_{3} \times$ Solid Berseem & ---- & -.-- & --- & 0.36 & ---- & ---- & -.-- & 1 & 1 \\
\hline
\end{tabular}

barley increased with increasing the rates of seeding fahl berseem, as well as the (RY) of fahl berseem increased with increasing these rates. These findings are in agreement with those of Kamel et al., (1991), Abdel-Zaher et al., (2009) and Karadage (2004).

\subsubsection{Total income}

Data presented in Table (10) indicate the effect of cutting and intervals and intercropping system on economic returns such as total gross returns, net returns and benefit to cost ratio benefit to cost ratio (B:C) for combined seasons and compared with each of them as a solid crop due to market price as economic expresser in terms of the farmer. Results showed that cutting intervals at harvest $\operatorname{day}\left(\mathrm{C}_{3}\right)$ gave the highest values on total gross returns, net returns and (B:C) was achieved by cutting.

Also the intercropping system, (barley $100 \%$ + berseem $75 \%)\left(\mathrm{T}_{3}\right)$ reached the highest values on the total gross returns, net returns and benefit to cost $(\mathrm{B}: \mathrm{C})$, respectively. For the interaction effect of cutting intervals $x$ intercropping system, $\left(\mathrm{C}_{3} \times \mathrm{T}_{3}\right)$ gave the highest values on the total gross returns, net returns and (B:C), respectively. On the contrary, the lowest value of net income (L.E. fed ${ }^{-1}$.) was achieved by intercropping system $\left(\mathrm{T}_{1}\right)$ including $(100 \%$ barley $+25 \%$ berseem). The advantage of cropping patterns barley and berseem as economic expresser in terms of the farmer, total income increased in all intercropping system compared to the total income of sole barley treatment. Similar results were obtained by Abd El-Zaher et al., (2009).

\section{Conclusion}

it could be recommended that the applied cutting interval (at 75 days) and intercropping system $(100 \%$ barley $+75 \%$ fahl berseem) must be used under the conditions of the soil at Giza as a good practice to maximize the economic return of grain yield and forage yield. 
Table (10): Estimates of costs for inputs farm operations and as affected by cutting interval, intercropping system and their interaction in 2013/14 and 2014/15 at Giza (combined analysis).

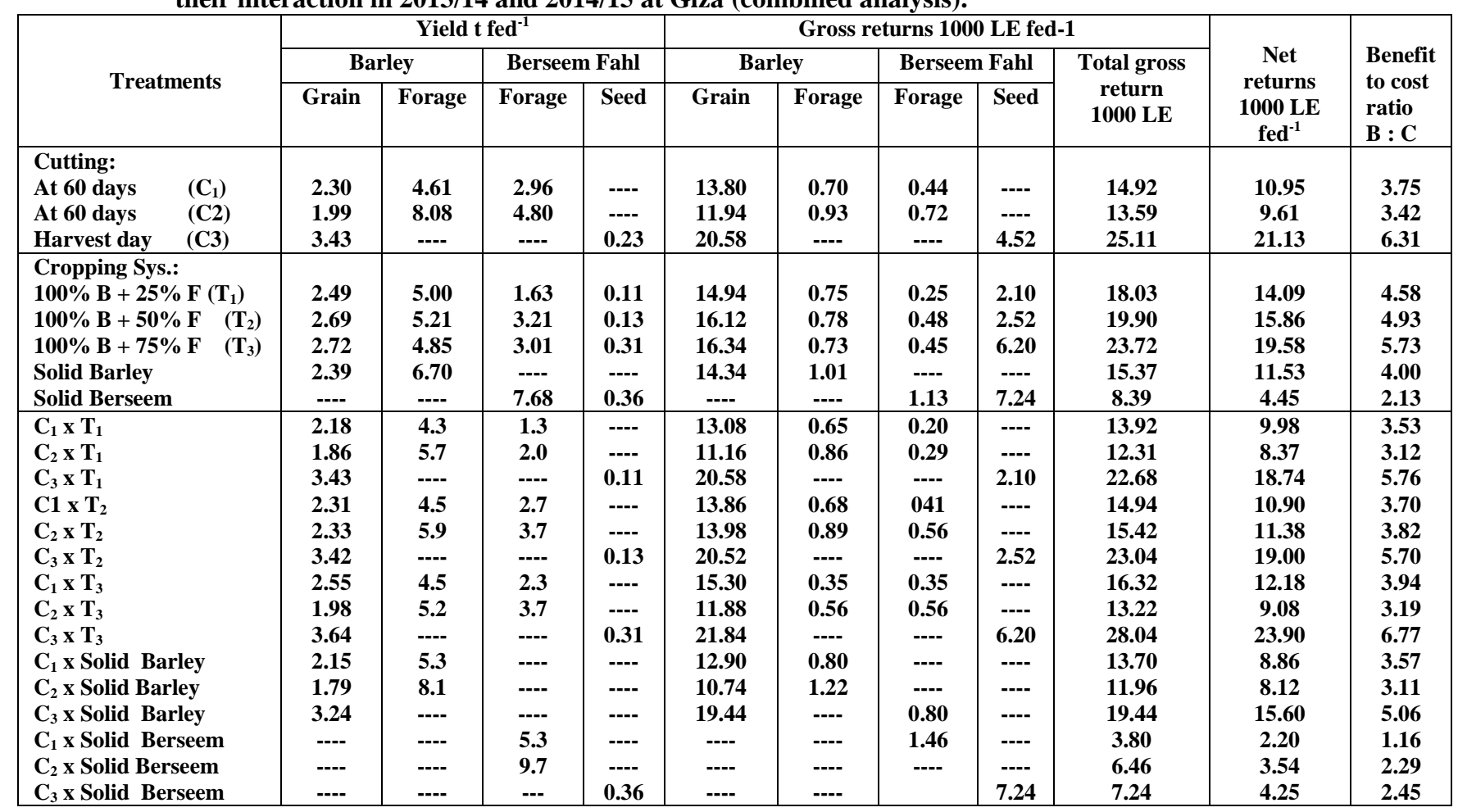

Mean of costs of production inputs over two years LE/fed:

Land preparation Tillage $=450$, Planting $=480$, Price of barley and berseem $($ fahl $)$ seeds $=6$ and $20 \mathrm{LE} / \mathrm{kg}$, respectively, irrigation $=400$, Ammonium nitrate (33.5\% N)= $540\left(1 \mathrm{~kg} \mathrm{~N}=13.43\right.$ L.E), Superphosphate $\left(15.5 \% \mathrm{P}_{2} \mathrm{O}_{5}\right)=450$, Potassium sulphate $\left(48 \% \mathrm{~K}_{2} \mathrm{O}\right)=800$, Hoeing and weeding $=720$, harvesting $=1000$, constant coast $=5400 \mathrm{~L} . \mathrm{E} / \mathrm{fed}$

Price of ton forage yield $=150$ LE. Net return $\left(\right.$ L.E.fed $\left.{ }^{-1}\right)=$ Total revenue - Total variable costs Benefit to cost ratio $(B$ : C $)$ L.E. $=$ Total gross returns/ Total variable costs, Net return of invested L.E. = Benefit to cost ratio (B : C) L.E - 1

\section{REFERENCES}

Abd El-Gawad K. I. (1993). Effect of Cutting Management on Forage, Protein and Seed Yields of Berseem clover (Synthetic 79 var.). Zagazig J. Agric. Res, Zagazig Univ., 20 (1A):67-75.

Abdel-Zaher Sh.R., Abdel-Galil M. A. and Ibrahim Sahar T. (2009). Effect of seeding rates of Fahl berseem mixed with wheat under three rates of nitrogen fertilizer on yield and yield components of both crops J.Agric.Sci. Mansoura Univ., 34(6): 3511.

Abou-Kerisha M.A., Mousa M.E. and Abd ELHamid M. (1996). Effect of growing fahl berseem with barley on forage and seed production in middle Egypt. Proc. $7^{\text {th }}$ Conf Agronomy, Mansoura Univ., 9-10 Sept., 1996, Mansoura, Egypt pp:579-588.

Anonymous (2014). "Field Crops Statistical year Book". Ministry of Agriculture and Land Reclamation, Egypt.

AOAC (2000). Official Methods of Analysis of the Association of Official Analytical Agricultural Chemists, $17^{\text {th }}$ Ed. Published by A.O.A.C., Washington D.C.,USA.
Boquet D.J, Koohce K.L and Walker D.M. (2003). Selected determinate soybean cultivar yield responses to row spacing's and planting dates. Agronomy Journal 74 , 136-138.

Caballero R.C., Alzueta L.T., Ortiz M.L., Rodriguez R.T. and Barro C. (2001). Carbohydrate and protein fractions of fresh and dried common vetch in three maturity stages. Agronomy Journal.93, 1006-1013.

Church D. C. (1979). Livestock Feeds and Feeding. D\&B book, $4^{\text {th }}$ ed., Lne. Corvallis, ISBN 10: 0960158618, Mishawaka, U.S.A.

FAO (2006). Food and Agriculture Organization of the United Nations. Available at Ghanbari A, Lee HC. 2002. Intercropped field beans and wheat for whole crop forage: Effect of nitrogen on forage yield and quality. Cambridge Journal 138, 311-314.

Gustave N.M., Jean F, Ois L. and Xavier D. (2008). Shoot and root competition in 
potato/maize intercropping: Effects on growth and yield. Journal Environmental and Experimental Botany 64(2), 180-188.

Haggag M. El-H, Marei Z. M. and El-Nahrawy M. Z. (1995).Performance of mixture on ten ryegrass varieties with Egyptian clover in comparison with pure stand.J. Agric.Sci.Mansoura. Univ.20(11):45374547.

Kamel A.S., EL-Masry M.A., EL-Mihi M.M., Metwally I.O. and EL-Gamel A.S. (1991). Effect of seeding rates of fahl berseem in mixtures of wheat and berseem for seed production.Egypt.J.Appl.Sci.,6(8)233-238.

Karadage Y. (2004). Intercropping berseem clover with barley and oat cultivars for forage.Agron. J., 96(6):1719-1729.

Mcdonald P., Edward R. A. and Greenhalgh J. F. (1978). Animal Nutrition. Longman Group Up; London, UK.

Nor EL-Din M.A., Gabra M.A. and Youssef E.Z. (1984). The Effect of nitrogen fertilization productivity of berseem and barley mixtures. Proc. EMCIP Symp. Field Crop Res. Inst. Giza, 2(84): 122128.

Page A.L., Miller R.H. and Keeney D.R. (1982). Methods of Soil Analysis. Part 2: Chemical and Microbiological Properties. Published in Soil Sci. Amer., Madison Wisconsin, USA.

Radwan M. S., Abd El-Hafeez A. A., Abdallah Hussein M., Abd El Gawad and El Zanaty R. I. (1983). Seed production in Fahl berseem intercropped with barley. Proc. 1st Conf. on Agron. Egypt Soc. Crop Sci. 1: $63-170$.
Sara N., Bonjar A. G., Ramroudi M. and Sirousmehr A. (2014). Evaluation of yield and yield components in intercropping of barley with clover. Inte. J., Agron. and Agric. Res. (IJAAR), 5, (4)P: 31-39.

Sekamatte B.M., Ogenga-Latigo M. and Russell-Smith A. (2003). Effects of maize-legume intercrops on termite damage to maize, activity of predatory ants and maize yields in Uganda. Journal of Crop Protection 22(1), 87-93.

Shendy M. Z. (2015). Evaluation of four new barley cultivars protectively intercropped with barsssem clover at different seeding rates in new land in Egypt. Bull. Fac. Agric. Cairo Univ., 66: 29 - 39.

Snedecor G. W. and Cochran W.G. (1980). Statistical methods $7^{\text {th }}$ Ed. Iowa State Univ.USA.

Stout D.G., Brooke B., Hall J.W. and Thompson D.J. (1997). Forage yield and quality from intercropped barley, annual ryegrass and different annual legumes. Grass Forage Sci. 52:298-308.

Willey R.W. and Rao M.R. (1980). A competitive ratio for quantifying competition between intercrops. Exp. Agric., 16: 117-125.

Yang G. D., Aiwang S., Jingsheng L. , Fusheng L. , Zugui L. Hao and Zhandong L. (2009). Crop coefficient and water-use efficiency of winter wheat/spring maize strip intercropping. Journal of Field Crops Research 111(2), 65-73. 
تأثير مواعيد الحش ونظم التحميل للبرسيم الفحل مع الثعير على إنتاجية الحبوب والعلف وقيمة المخلوط الغذائية

عبد الجليل محمد عبد الجليل- حن عبد الجليل عثماوي* _صلاح سالم محمد أبو فتيح **-ـ هانم السيد احمد النادي*

قسم بحوث التكثيف المحصولى ، * قسم بحوث الثعير _* * قسم بحوث محاصيل العلف ، معهد بحوث المحاصيل الحقلية

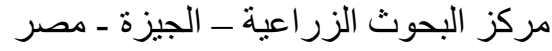

\section{ملخص}

أجريت هذه التجربة في محطة التجارب للبحوث الزر اعية بمحافظة الجيزة، مصر ، خلال موسمي

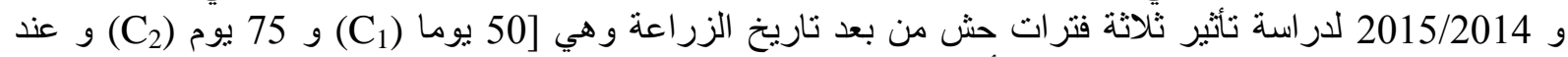

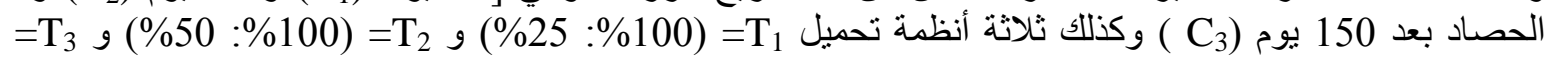

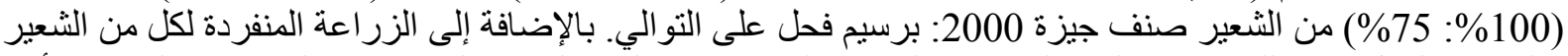

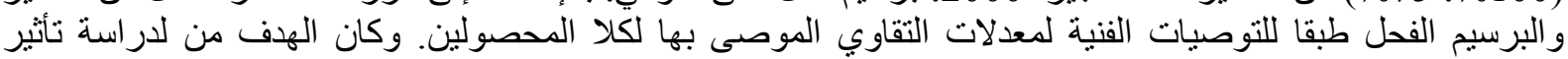

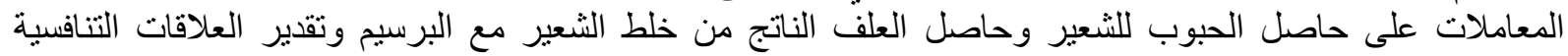

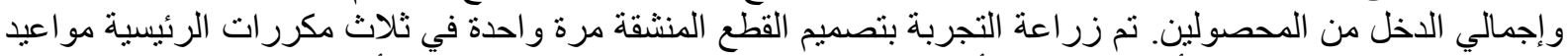

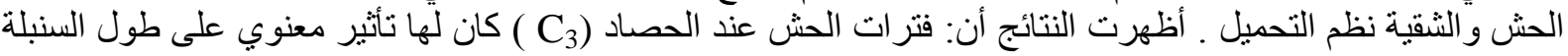

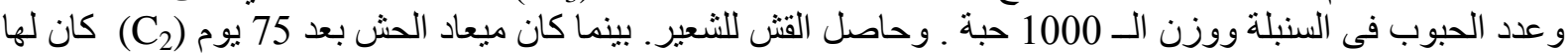

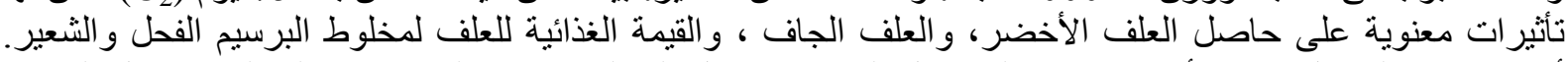

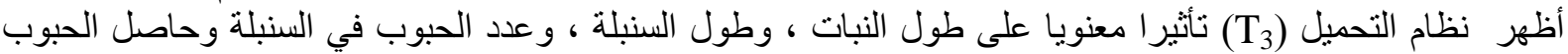

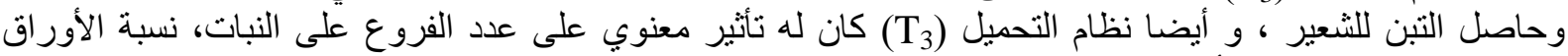

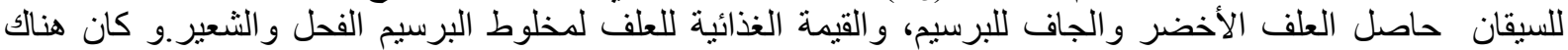
معنوية عالية للتفاعل بين ميعاد الحش ونظام التحميل (C.

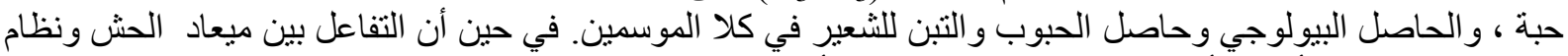

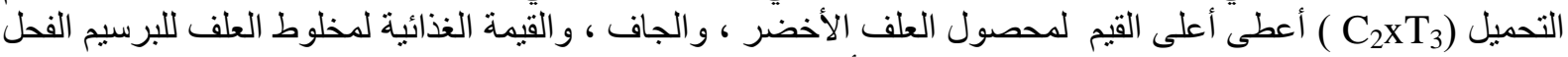

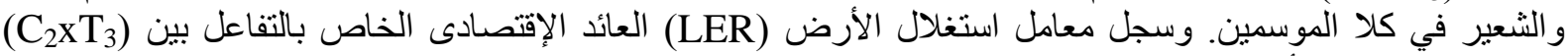

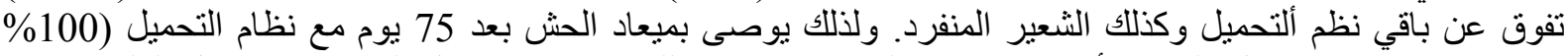

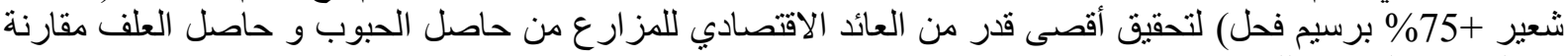
مع الزر اعة المنفردة للشعير. 